\title{
Identification and Antibiotic Susceptibility of Blood Culture Isolates from Rajshahi, Bangladesh
}

\author{
Tamanna Zerin $^{1 *}$, Md. Ariful Islam ${ }^{1,2}$, Sabera Gulnahar ${ }^{3}$, Noor E Farjana ${ }^{1}$, Mosammat Asia \\ Begum $^{1}$, Halima-E-Sadia ${ }^{1}$ \\ ${ }^{1}$ Department of Microbiology, Stamford University Bangladesh, 51, Siddeswari Road, Dhaka-1217, \\ Bangladesh. \\ ${ }^{2}$ Jazeera diagnostic center, Kajihata, Lakhmipur, Rajshahi, Bangladesh. \\ ${ }^{3}$ Rajshahi medical college hospital, Rajshahi, Bangladesh.
}

\begin{tabular}{|c|c|}
\hline Article Info & Abstract \\
\hline $\begin{array}{l}\text { Article history: } \\
\text { Received:10 March } 2021 \\
\text { Revised: } 23 \text { May } 2021 \\
\text { Accepted:25 May } 2021\end{array}$ & $\begin{array}{l}\text { Purpose: As bloodstream infection is a significant cause of morbidity and } \\
\text { mortality, the surveillance study is required to continuously monitor the } \\
\text { pattern of infection and antibiotic resistance. Our study aimed to detect } \\
\text { the antibiotic susceptibility pattern of bacteria isolated from patients in } \\
\text { Rajshahi, Bangladesh. } \\
\text { Subiects and Methods: This study was conducted over } 2 \text { vears from }\end{array}$ \\
\hline $\begin{array}{l}\text { Keywords: } \\
\text { Bloodstream Infection } \\
\text { Gram-negative, } \\
\text { Gram-positive, } \\
\text { Antibiogram, } \\
\text { Bangladesh }\end{array}$ & $\begin{array}{l}\text { January } 2019 \text { to December } 2020 \text { with a total of } 1,367 \text { suspected } \\
\text { hemocultures of inward and outward patients in Rajshahi medical college } \\
\text { hospital, Rajshahi, Bangladesh. The standard microbiological methods } \\
\text { were used in this study. } \\
\text { Results: Out of overall } 35 \% \text { positive growth, } 34 \% \text { and } 37 \% \text { showed blood } \\
\text { culture infection in the year } 2019 \text { and } 2020 \text {, respectively. Females (55\%) } \\
\text { were found higher than males (45\%). The patients were the highest in the } \\
\text { age group 0-10 years (46\%) but the number of infections rapidly } \\
\text { decreased in the age } 11-20 \text { years (21\%) followed by a gradual reduction } \\
\text { of infection with the increasing age. All the infections were occurred due } \\
\text { to single culture and E. coli was accounted as the most frequent infection }\end{array}$ \\
\hline $\begin{array}{l}\text { Correspondence Author } \\
\text { Tamanna Zerin } \\
\text { Email: } \\
\text { tzerin1983@gmail.com }\end{array}$ & $\begin{array}{l}\text { (39.09\%) followed by Staphylococcus aureus, Candida albican, } \\
\text { Klebsiella pneumonia, Staphylococcus epidermidis, Salmonella spp., } \\
\text { Streptococcus viridans and Pseudomonas aeruginosa. Higher sensitivity } \\
\text { towards Cefepime, and Meropenem was demonstrated by both Gram- } \\
\text { negative and Gram-positive bloodborne bacteria. A terrifying scenario } \\
\text { was that a great number of those isolates showed resistance towards } 4,6 \text {, } \\
\text { and more than } 6 \text { antibiotics, respectively. } \\
\text { Conclusion: Our local work on bacteriological profile and antibiogram } \\
\text { might help to rationalize empiric treatment strategies. }\end{array}$ \\
\hline
\end{tabular}

\section{Introduction}

A disease that is transmitted by blood or body fluid is known as blood-borne disease. Blood is normally sterile until it is contaminated (Castillo et al., 2019). The presence of microorganisms in the blood is addressed by different terms, like bacteremia (presence of bacteria in the blood), viremia (presence of virus in the blood), fungemia (presence of fungi in the blood) (Viscoli, 2016). However, gram-negative bacteria are more common in bacteremia causing $25 \%$ of nosocomial infections and $45 \%$ of community-acquired infections (Gaynes \& Edwards, 2005; Diekema, 2003). The common gram-negative bacteria that are responsible for bacteremia include Escherichia coli, Pseudomonas, Klebsiella, Serratia, 
Salmonella, Enterobacter, etc. (Ahmed et al., 2017; Mia and Zerin, 2020). Whereas, Staphylococcus, Streptococcus and Enterococcus species are the major gram-positive bacteria that can enter the bloodstream during infection (Rolston et al., 2006).

Antibiotic resistance is a major concern worldwide and, in the USA, around 2 million illnesses and 23,000 deaths per year are caused by antibiotic-resistant bacteria. If the recent scenario continues, by 2050, the death may rise to 10 million/year worldwide where about 90\% of the predicted death might occur in developing countries like Asia and Africa (Laxminarayan et al., 2013; Islam et al., 2019). People from Indian subcontinents are using $3^{\text {rd }}$ or $4^{\text {th }}$ generation antibiotics whereas $1^{\text {st }}$ or $2^{\text {nd }}$ generation antibiotics are being consumed by European or American people (Farooqui et al., 2018). Bangladesh and neighbouring countries contributed a mammoth risk due to inconsiderable uses and misuses of antibiotics, thus, bacteria become resistant and can be able to proliferate in presence of antibiotics (Islam, 2020). To address the forthcoming threat of antibiotic resistance, this is a must to continue systemic regional surveillance through comprehensive monitoring and analysis of the frequency of occurrence and trends of resistance to properly conduct interferences. Hence, our study endeavoured to detect the occurrence of microorganisms in bloodborne infections and their antibiotic susceptibility pattern for 23 months in a hospital situated in Rajshahi, Bangladesh.

\section{Methodology and Procedures}

The study was carried out in Rajshahi medical college hospital, Rajshahi, Bangladesh over a period from January 2019 to November 2020. A total of 1,367 samples of inward and outward patients clinically suspected as having bacteremia were evaluated for our study. The standard microbiological methods were used in this study.

In paediatric cases, 1-2 $\mathrm{mL}$ of blood was collected and directly incorporated into blood culture bottles (Microbiotech S.r.l., Maglie, Italy). In adults, blood samples of 5-10 mL were collected and directly incorporated into blood culture bottles (Microbiotech S.r.l., Maglie, Italy). The bottles were incubated at $37^{\circ} \mathrm{C}$ aerobically for visible growth to come. Following visible growth, 2-3 drops of the blood culture were inoculated on blood agar (Oxoid) and MacConKey agar (Oxoid) media. Blood culture bottles that do not show any significant growth till the 7 th day of incubation were reported as culture negative. The culture-positive samples were identified by colony morphology, microscopy, and conventional biochemical tests as per the standard protocol followed in the microbiology laboratory (Collee et al., 1996).

The antibiotic susceptibility pattern of bacterial isolates was performed by KirbyBauer disc diffusion method on Mueller-Hinton agar plate, and the results were recorded following the Clinical and Laboratory Standards Institute 2015 guidelines (Wayne, 2016). Various categories of antibiotics were used in our study, including aminoglycosides (Amikacin $25 \mu \mathrm{g}$ and Gentamycin $10 \mu \mathrm{g}$ ), carbapenems (Imipenem $10 \mu \mathrm{g}$, Aztreonam $30 \mu \mathrm{g}$, Meropenem $10 \mu \mathrm{g}$ ), cephalosporins (Cephradine $30 \mu \mathrm{g}$, Ceftazidime $30 \mu \mathrm{g}$, Ceftriaxone 30 $\mu \mathrm{g}$, Cefixime $05 \mu \mathrm{g}$, Cefepime $30 \mu \mathrm{g}$, Cefuroxim Sodium $30 \mu \mathrm{g}$ ), penicillins (Cloxacillin 05

$\mu \mathrm{g}$, Penicillin G $6 \mu \mathrm{g}$ ), fluoroquinolones (Levofloxacin $05 \mu \mathrm{g}$, Moxifloxacin $05 \mu \mathrm{g}$ and Ciprofloxacin $05 \mu \mathrm{g}$ ), macrolides (Azithromycin $15 \mu \mathrm{g}$ ), oxazolidinones (Linezolid $10 \mu \mathrm{g}$ ), 
tetracyclines (Doxycycline $30 \mu \mathrm{g}$ ), nitrofuran antibiotics (Nitrofurantoin $300 \mu \mathrm{g}$ ), polymyxin (Colistin Sulphate $10 \mu \mathrm{g}$, Polymyxin B $50 \mu \mathrm{g}$ ) and sulfonamides (Cotrimoxazole $25 \mu \mathrm{g}$ ).

\section{Results and Discussion}

A 2-year extended study was carried out from January 2019 to December 2020 with a total of 1,367 suspected hemocultures. Among them, 481 cultures showed growth and 886 cultures did not show $\backslash$ any growth. In both of the years, the number of positive samples increased or decreased in a much-synchronized pattern throughout the years. Whereas, the highest number of positive specimens was observed in March in both of the years. However, the number of positive samples bottomed in July 2019 and November 2020. The month-wise distribution of growth positive and growth negative specimens for the years 2019 and 2020 was depicted in Figure 1. The year-wise frequency of positive and negative specimens was summarized in percentage in Figure 2. Of the total samples, 34\% in 2019 and $37 \%$ in 2020 yielded significant growth of blood-borne pathogens. Positive samples were almost half of the negative samples over the two different years.

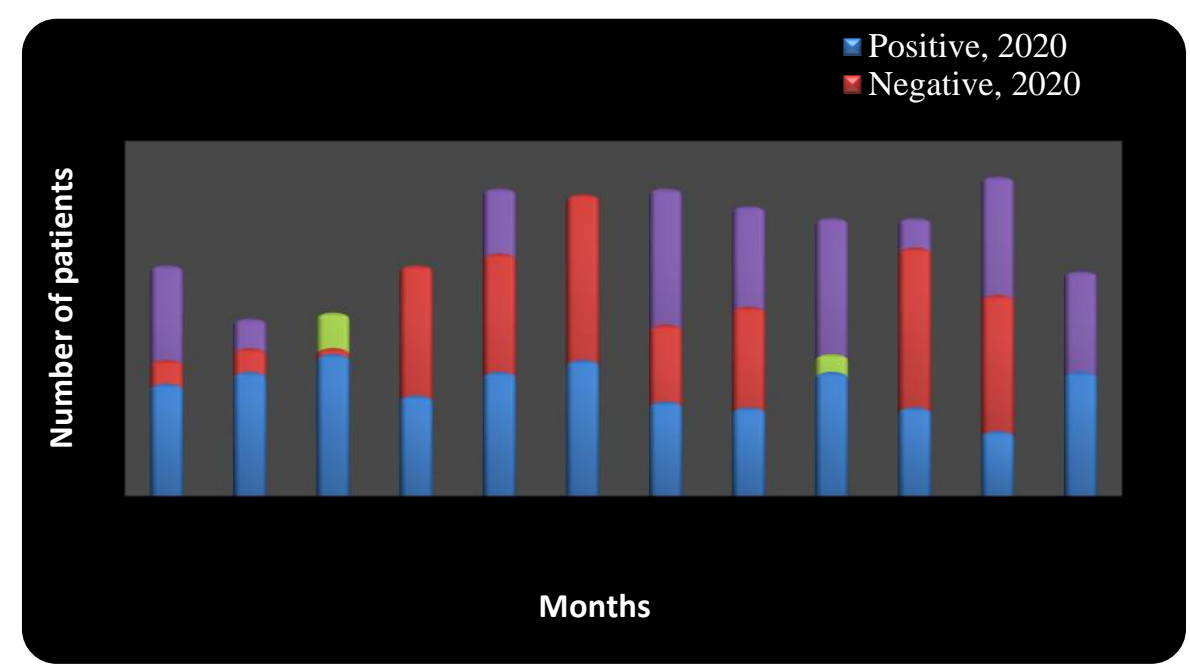

Figure 1: The bar diagram presented the frequency distribution of positive and negative samples in every month of the year 2019 and 2020.
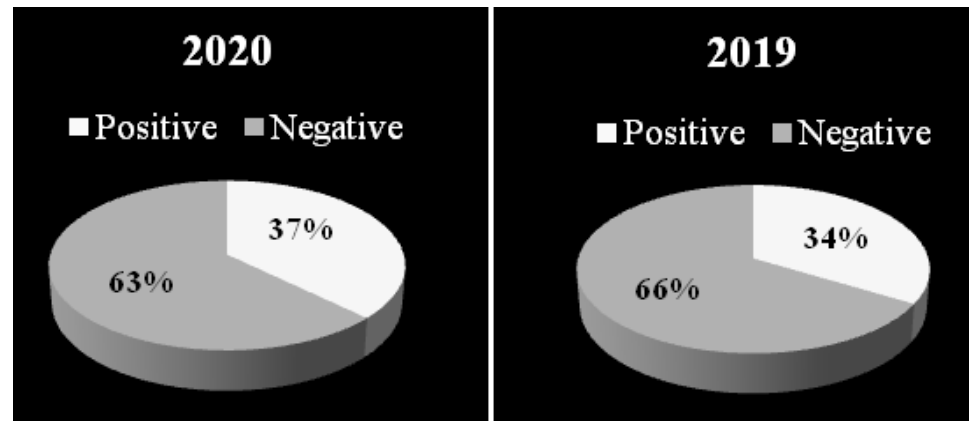

Figure 2: The pie graph showed the percentage of total positive and negative specimens in 2020 and 2019. 


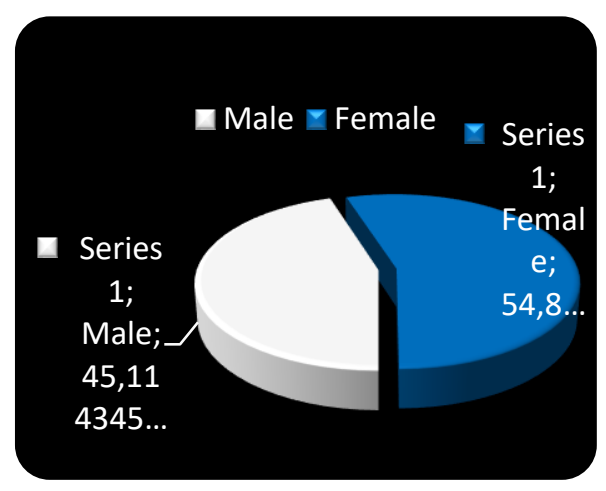

Figure 3: The pie chart showed the percentage of total male and female patients throughout the study period.

Our data showed that females were somewhat more prone $(55 \%)$ to bloodborne diseases than males (45\%) which is illustrated in Figure 3. The bar graph showed the agewise distribution of both male and female patients throughout the study period (Figure 4).

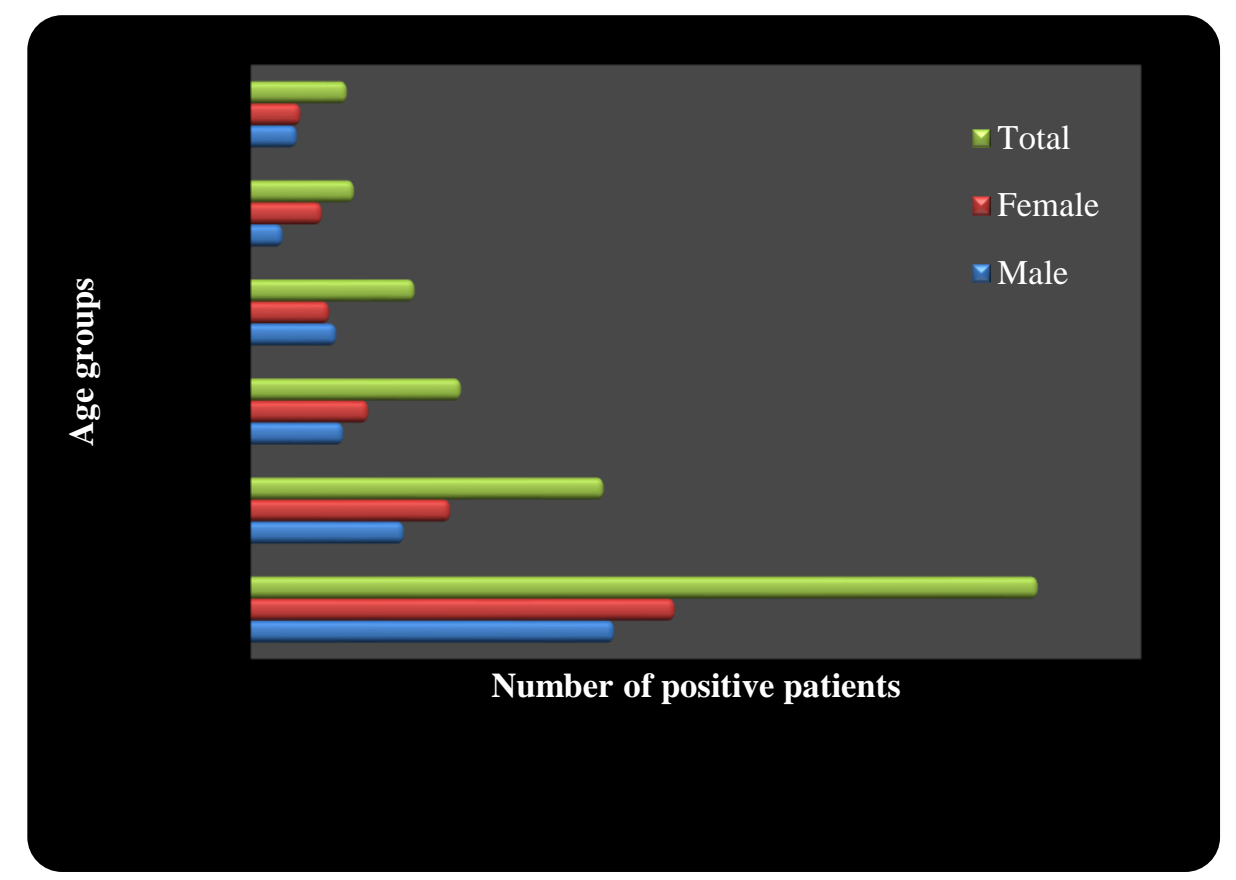

Figure 4: The bar diagram presented the age-wise distribution of male, female and total patients in the study period.

The positive patients were age-wise divided into 6 categories as 0-10, 11-20, 21-30, 31-40, 41-50, and $51^{+}$. Overall, it was observed that the number of infected patients declined with the increase of their age. However, the number of infections is very high in the early age group (0-10). All the infections were occurred due to single culture. E. coli accounted for $39.09 \%$ of infections which was the most frequent organism followed by Staphylococcus aureus (34.93\%), Candida albicans (14.76\%), Klebsiella pneumoniae (3.95\%), Staphylococcus epidermidis (3.12\%), Salmonella spp. (2.70\%), Streptococcus viridans $(1.04 \%)$ andPseudomonas aeruginosa $(0.42 \%)$ (Table 1$)$.

Table 1: Distribution of Microorganisms isolated from blood samples. 


\begin{tabular}{lll} 
Bacterial isolates & Number & $\%$ \\
\hline E. coli & 188 & 39.09 \\
Staphylococcus aureus & 168 & 34.93 \\
Candida albicans & 71 & 14.76 \\
Klebsiella pneumoniae & 19 & 3.95 \\
Staphylococcus epidermidis & 15 & 3.12 \\
Salmonella spp. & 13 & 2.70 \\
Streptococcus viridans & 5 & 1.04 \\
Pseudomonas aeruginosa & 2 & 0.42 \\
\hline Total & 481 & 100.01
\end{tabular}

The analysis of antibiotic sensitivity patterns of gram-negative and gram-positive bloodborne bacteria revealed higher sensitivity towards Cefepime and Meropenem. No bacteria were found to acquire complete sensitivity or resistance towards all the antibiotics, as well, none of the antibiotics showed complete sensitivity or resistance by all the bacteria. Most of the bacteria showed a degree of resistance or sensitivity towards the antibiotics. However, all the gram-positive bacteria showed the greatest sensitivity for Meropenem. A degree of drug sensitivity pattern was observed by most of the isolates. Moreover, the lowest sensitivity was observed by $E$. coli against Cefuroxim sodium, and Ceftriaxone, by $P$. aeruginosa against Aztreonam and Colistin Sulphate, by K. pneumonia against Ceftriaxone, and Moxifloxacin, by Salmonella spp. against Co-trimoxazole and Ciprofloxacin, by $S$. aureus against Azithromycin and Linezolid, by S. epidermidis against Gentamicin, by $S$. viridans against Cloxacillin (Table 2). However, our data revealed a terrifying scenario where $57.32 \%$ of isolates showed resistance to 4 antibiotics. No isolates were found to only one antibiotic. Moreover, $3.41 \%$ and $2.68 \%$ of the isolates were resistant to 6 and more than 6 antibiotics, respectively (Figure 3).

Table 2: Antibiotic sensitivity pattern of bacteria isolated from blood culture

\begin{tabular}{|c|c|c|c|c|c|c|c|c|c|c|c|c|c|c|c|c|c|c|c|c|c|c|c|c|}
\hline 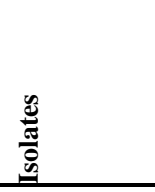 & 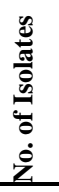 & 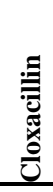 & 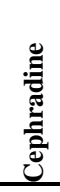 & 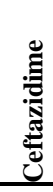 & 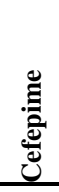 & 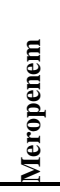 & 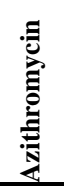 & 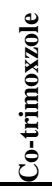 & 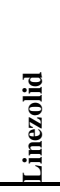 & 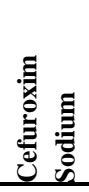 & 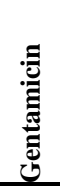 & 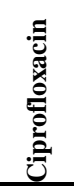 & 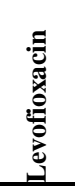 & 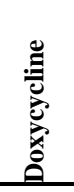 & 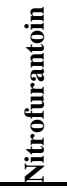 & 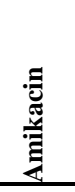 & 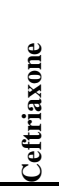 & 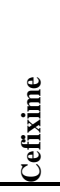 & 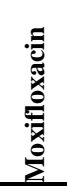 & 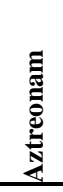 & 竞竞 & 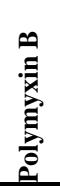 & 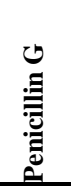 & 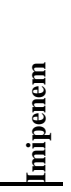 \\
\hline \multicolumn{25}{|c|}{ Gram negative bacteria } \\
\hline E. coli & $\stackrel{\infty}{\infty}$ & 之 & 之 & 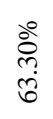 & $\begin{array}{l}\stackrel{8}{8} \\
\stackrel{\infty}{\circ}\end{array}$ & $\begin{array}{l}\stackrel{8}{\circ} \\
\stackrel{2}{\circ} \\
8\end{array}$ & 之 & 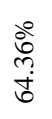 & 之 & $\begin{array}{l}\stackrel{0}{0} \\
\dot{0} \\
\dot{y}\end{array}$ & 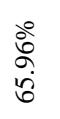 & $\begin{array}{l}\stackrel{8}{0} \\
\stackrel{\leftrightarrow}{1} \\
\stackrel{+}{n}\end{array}$ & $\begin{array}{l}\stackrel{0}{\infty} \\
\stackrel{+}{1} \\
\stackrel{i}{i}\end{array}$ & $\begin{array}{l}\stackrel{0}{\circ} \\
\dot{q} \\
\dot{b}\end{array}$ & $\begin{array}{l}\stackrel{\circ}{=} \\
8\end{array}$ & $\begin{array}{l}\delta_{0}^{0} \\
\text { ț } \\
\stackrel{0}{0}\end{array}$ & $\begin{array}{l}\stackrel{0}{0} \\
\otimes \\
\dot{J}\end{array}$ & $\frac{80}{=}$ & $\begin{array}{l}\stackrel{\circ}{2} \\
\dot{+}\end{array}$ & \begin{tabular}{l}
$\frac{0}{d}$ \\
\multirow{a}{a}{} \\
co
\end{tabular} & 之 & 之 & 之 & $\begin{array}{l}\underbrace{\circ} \\
i \\
+ \\
\infty\end{array}$ \\
\hline $\begin{array}{l}P . \\
\text { aeruginosa }\end{array}$ & $\tilde{\delta}$ & 之 & 之 & $\stackrel{8}{\circ}$ & $\stackrel{\circ}{\circ}$ & $\stackrel{\circ}{\circ}$ & 之 & 乙 & 之 & 之 & $\stackrel{8}{8}$ & 官 & ठ̊ํ & 会 & 之 & $\stackrel{\circ}{\circ}$ & 之 & 之 & $\stackrel{\circ}{n}$ & 80 & 80 & @̊̊̊ & 之 & $\stackrel{8}{\circ}$ \\
\hline $\begin{array}{l}\text { K. } \\
\text { pneumoniae }\end{array}$ & $\stackrel{2}{2}$ & 之 & 之 & 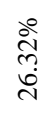 & $\begin{array}{l}\stackrel{\circ}{\stackrel{+}{+}} \\
\stackrel{0}{\infty}\end{array}$ & $\begin{array}{l}\stackrel{0}{0} \\
\alpha \\
\infty \\
\infty\end{array}$ & 之 & 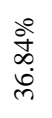 & 之 & 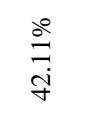 & 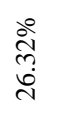 & 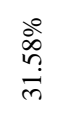 & $\begin{array}{l}\stackrel{8}{8} \\
\stackrel{9}{+} \\
\dot{q}\end{array}$ & 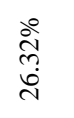 & 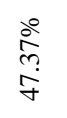 & 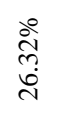 & $\begin{array}{l}\stackrel{\circ}{\circ} \\
\stackrel{+}{+}\end{array}$ & $\begin{array}{l}\stackrel{\circ}{\infty} \\
\stackrel{n}{m} \\
\stackrel{m}{m}\end{array}$ & $\begin{array}{l}\stackrel{0}{0} \\
\stackrel{2}{\dot{c}} \\
\dot{\lambda}\end{array}$ & $\begin{array}{l}\stackrel{0}{D^{2}} \\
? \\
\dot{y}\end{array}$ & 之 & 之 & 之 & 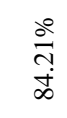 \\
\hline $\begin{array}{l}\text { Salmonella } \\
\text { spp. }\end{array}$ & $\underline{m}$ & 乙 & 之 & $\begin{array}{l}\stackrel{8}{\pi} \\
\text { వి }\end{array}$ & $\stackrel{\circ}{\circ}$ & $\stackrel{\circ}{\circ}$ & 之 & $\begin{array}{l}\infty \\
\infty \\
\substack{n \\
n}\end{array}$ & 之 & 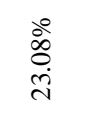 & 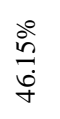 & $\begin{array}{l}\infty \\
\infty \\
i \\
n \\
n\end{array}$ & 之 & 之 & $\begin{array}{l}\text { ڤ̊ } \\
\text { فे }\end{array}$ & $\begin{array}{l}\stackrel{80}{h} \\
\stackrel{6}{b}\end{array}$ & $\begin{array}{l}\stackrel{8}{0} \\
\text { å }\end{array}$ & $\begin{array}{l}\dot{8} \\
\dot{c} \\
\infty \\
\infty\end{array}$ & $\begin{array}{l}80 \\
\dot{c} \\
\infty \\
\infty \\
\infty\end{array}$ & $\begin{array}{l}\text { ڤ̊ } \\
\text { فे }\end{array}$ & 之 & 之 & 之 & $\stackrel{8}{\circ}$ \\
\hline
\end{tabular}




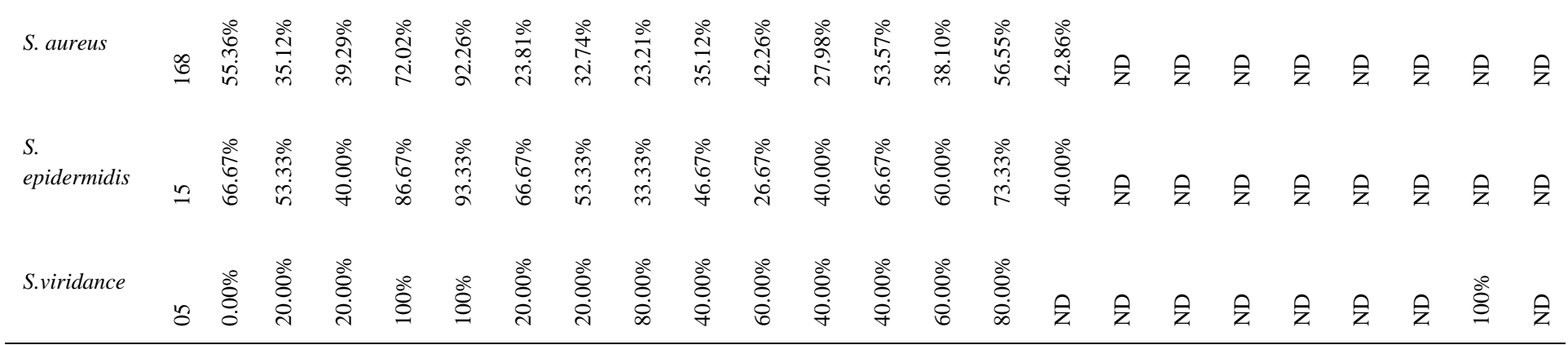

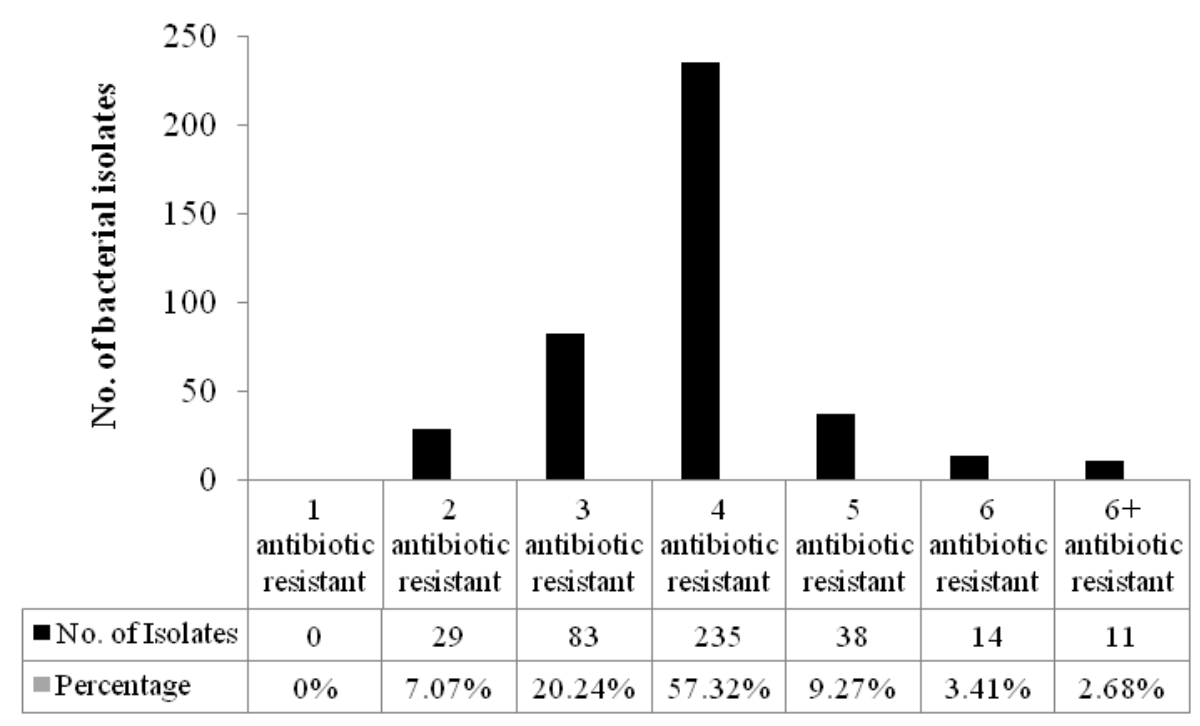

Figure 5: The bar diagram depicts the number of bacterial isolates that were resistant towards 1 to more than 6 antibiotics.

\section{Discussion}

Pathogenic organisms can enter into the blood that is an important factor for various infections like circulatory system infections and local infections (Ruiz-Giardin et al., 2013). Because of the increasing antibiotic resistance, it becomes indispensable to diagnose and discover adequate treatment against antimicrobial resistance. This study strengthens the age-, sex- and month-wise distribution of suspected patients and the prevalence of bacterial pathogens responsible for bloodstream infections with their antimicrobial resistance over a 2year study period from January 2019 to December 2020. In both of the years, about one-third of the total patients were tested as positive which is quite higher compared to other studies (Mehta et al., 2005; China and Gupta, 2013). Nevertheless, the number varies in different regions due to technical differences in identifying infection, and use of antibiotics before culture or sensitivity tests (Shrestha et al., 2014; Gupta and Kashyap, 2016). The month, March was the most critical time for patients because it accounted for the highest number of infections in both of the years. The highest number of infections were found in the youngest age group that was 10 or below 10 years might be due to the weaker immune system. However, patients who are above 50 years old represented the least number of infections which co-related with a study published in 2016, showed the highest infection was found in 
neonates $(38.71 \%)$, where, the least infection was detected in elderly people (4.55\%) (Sweta et al., 2016). Our study found that women were comparatively more vulnerable to bloodborne infections than men although previous studies reported that males were more infected than females (Mia and Zerin, 2020; Weiss et al., 2005). However, there is no strong rationale considered behind the scenario where any gender could be more prone to blood-borne infections.

From our study, we observed the prevalence of bloodborne infection by gramnegative bacteria was 222, by gram-positive bacteria was 188 and by fungus 71 . Higher occurrence of gram-negative bacteria in bloodborne infections is common which correlates with previous studies (Mia and Zerin, 2020; Khanal, 2020; Mehdinejad et al., 2009; Barati et al., 2009; Ayobola et al., 2011) although it differs from some previous studies where grampositive bacteria took over the predominance in infection (China and Gupta, 2013; Kamgaet al., 2011; Anbumani et al., 2008).In our study, E. coli accounted for the most frequent organism followed by Staphylococcus aureus, Candida albicans, Klebsiella pneumoniae, Staphylococcus epidermidis, Salmonella spp., Streptococcus viridans and Pseudomonas aeruginosa. E. coli that gain access to and capable of surviving in the blood is called extraintestinal pathogenic E. coli which can cause urinary tract infection (UTI), sepsis, or neonatal meningitis. Among them, the most common site to colonize is the urinary tract, the reason for UTI (Daga et al., 2019).

Our study revealed that $4^{\text {th }}$ generation cephalosporin; Cefepime and Meropenem that belongs to the carbapenem class were the most sensitive antibiotics against both grampositive and gram-negative bacteria. However, Imipenem that also belonged to the carbapenem class showed great sensitivity against gram-negative bacteria which correlates with one previous study where they showed Imipenem was the most sensitive antibiotic against all gram-negative bacteria tested (Prabhu et al., 2010). Nitrofurantoin worked great against gram-positive bacteria. Subsequently, increasing resistance was observed against $3^{\text {rd }}$ generation cephalosporins like Ceftazidime, Ceftriaxone and Cefixime. The maximum resistance was observed by $E$. coli against Cefuroxim Sodium, and Ceftriaxone, by $P$. aeruginosa against Aztreonam, and Colistin Sulphate, by K. pneumonia against Ceftriaxone, and Moxifloxacin, by Salmonella spp. against Co-trimoxzole, and Ciprofloxacin, by $S$. aureus against Azithromycin, and Linezolid, by S. epidermidis against Gentamicin, by $S$. viridans against Cloxacillin. However, due to the unavailability of all of the antibiotics throughout the study period, susceptibility tests were not performed against all the antibiotics by all the isolates make it quite difficult to compare the pattern of sensitivity or resistance by all the isolates. However, an alarming scenario was that more than $90 \%$ of the isolates were resistant to 3 or more than 3 antibiotics. In one previous study, it was observed that $90 \%$ of the uropathogens were multi-drug resistant (Badri and Mohamed, 2017). Nevertheless, the easy access of antibiotics for self-therapy, treatment without a diagnosis, unnecessary use of antibiotics, irregular use, and stop taking antibiotics before completing the course might be responsible to generate bacteria with antibiotic resistance. Their easy dissemination into the environment is the reason people are getting infected by those resistant bacteria.

\section{Conclusion and Suggestion}


Our data revealed a very high resistance of bacterial isolates against commonly used antibiotics. Regional studies are required to uncover the scenario of that particular region to act on prevention and empirical treatment.

\section{Acknowledgements}

The authors hereby articulate their profound appreciation to the Rajshahi medical college hospital, Rajshahi, Bangladesh for the technical supports provided throughout the study period.

\section{Conflict of Interest}

None declared.

\section{Funding:}

The study was approved by the Institutional Ethics Committee, the Rajshahi Medical College hospital, Rajshahi, Bangl.adesh

\section{References}

Ahmed, D., Nahid, M. A., Sami, A. B., Halim, F., Akter, N., Sadique, T., Rana, M. S., Elahi, M. S., \& Rahman, M. M. (2017). Bacterial etiology of bloodstream infections and antimicrobial resistance in Dhaka, Bangladesh, 2005-2014. Antimicrobial resistance and infection control, 6, 2.

Anbumani, N., Kalyani, J., \& Mallika, M. (2008). Distribution and antimicrobial susceptibility of bacteria isolated from blood cultures of hospitalized patients in a tertiary care hospital. Indian Journal for the Practising Doctor, 5(2), 1-7.

Ayobola, E. D., Egbule, O. S., \& Omonigho, O. (2011). Study of prevalence and antimicrobial susceptibility of blood culture bacterial isolates. Malaysian Journal of Microbiology, 7(2), 78-82.

Badri, A. M., \& Mohamed, S. G. (2017). Clinical Epidemiology and Antibiogram of UTI Patients Attended Different Hospital in Khartoum, Sudan. Clinical Microbiology,6(5), 301.

Barati, M., Talebi-Taher, M., Abasi, R., Zadeh, M. M., Barati, M., \& Shamshiri, A. R. (2009). Bacteriological profile and antimicrobial resistance of blood culture isolates. Archives of Clinical Infectious Diseases, 4(2), 87-95.

Castillo, D. J., Rifkin, R. F., Cowan, D. A., \& Potgieter, M. (2019). The Healthy Human Blood Microbiome: Fact or Fiction?. Frontiers in Cellular and Infection Microbiology, 9, 148.

China, D., \& Gupta, V. (2013). Bacteriological profile and antimicrobial susceptibility pattern of blood isolates from a tertiary care hospital in North India. International Journal of Pharmaceutical Research and Bioscience, 2(2), 24-35.

Collee, J. G., Miles, R. S., \& Watt, B. (1996). Tests for the Identification of Bacteria. In: Collee, J.G., Marmion, B.P., Fraser, A.G. and Simmons, A., Eds., Mackie \& 
McCartney Practical Medical Microbiology, $14^{\text {th }}$ Edition, Churchill Livingstone, New York, 131-151.

Daga, A. P., Koga, V. L., Soncini, J., de Matos, C. M., Perugini, M., Pelisson, M., Kobayashi, R., \& Vespero, E. C. (2019). Escherichia coli Bloodstream Infections in Patients at a University Hospital: Virulence Factors and Clinical Characteristics. Frontiers in cellular and infection microbiology, 9, 191.

Diekema, D. J., Beekmann, S. E., Chapin, K. C., Morel, K. A., Munson, E., \& Doern, G. V. (2003). Epidemiology and outcome of nosocomial and community-onset bloodstream infection. Journal of clinical microbiology, 41(8), 3655-3660.

Farooqui, H. H., Selvaraj, S., Mehta, A., \& Heymann, D. L. (2018). Community level antibiotic utilization in India and its comparison vis-à-vis European countries: Evidence from pharmaceutical sales data. PloS one, 13(10), e0204805.

Gaynes, R. \& Edwards, J.R. (2005). Overview of nosocomial infections caused by gramnegative bacilli. Clinical Infectious Diseases, 41(6), 848-854.

Gupta, S., \& Kashyap, B. (2016). Bacteriological profile and antibiogram of blood culture isolatesfrom a tertiary care hospital of North India. Tropical Journal of Medical Research, 19(2), 94.

Islam, M.M. (2020). Bacterial resistance to antibiotics: access, excess, and awareness in Bangladesh. Expert Review of Anti-infective Therapy, 23, 1-9.

Islam, S., Aldstadt, J., \& Aga, D. (2019). Global antimicrobial resistance: a complex and dire threat with few definite answers. TropicalMedicineandInternationalHealth, 24(6), 658-62.

Kamga, H. L. F., Njunda, A. L., Nde, P. E., Assob, J. C. N., Nsagha, D. S., \& Weledji, P. (2011). Prevalence of septicemia and antibiotic sensitivity pattern of bacterial isolates at the University Teaching Hospital, Yaoundae, Cameroon. African Journal of Clinical and Experimental Microbiology, 12(1), 2-8.

Khanal, L. K. (2020). Bacteriological profile of blood culture and antibiogram of the bacterial isolates in a tertiary care hospital. International Journal of Health Sciences and Research, 10(8), 10-14.

Laxminarayan, R., Duse, A., Wattal, C., Zaidi, A. K., Wertheim, H. F., Sumpradit, N., Vlieghe, E., Hara, G. L., Gould, I. M., Goossens, H., Greko, C., So, A. D., Bigdeli, M., Tomson, G., Woodhouse, W., Ombaka, E., Peralta, A. Q., Qamar, F. N., Mir, F., Kariuki, S., ... Cars, O. (2013). Antibiotic resistance-the need for global solutions. The Lancet. Infectious diseases, 13(12), 1057-1098.

Mehdinejad, M., Khosravi, A. D., \& Morvaridi, A. (2009). Study of prevalence and antimicrobial susceptibility pattern of bacteria isolated from blood cultures. Journal of Biological Sciences, 9(3), 249-253.

Mehta, M., Dutta, P., \& Gupta, V. (2005). Antimicrobial susceptibility pattern of blood isolates from a teaching hospital in north India. Japanese journal of infectious diseases, 58(3), 174-176.

Mia, A., \& Zerin, T. (2020). Antibiogram of blood culture isolates of patients from a hospital in Dhaka, Bangladesh. Matrix Science Medica, 4, 1-5.

Prabhu, K., Bhat, S., \& Rao, S. (2010). Bacteriologic profile and antibiogram of blood culture isolates in a pediatric care unit. Journal of laboratory physicians, 2(2), 85-88. 
Rolston, K. V., Yadegarynia, D., Kontoyiannis, D. P., Raad, I. I., \& Ho, D. H. (2006). The spectrum of gram-positive bloodstream infections in patients with hematologic malignancies, and the in vitro activity of various quinolones against gram-positive bacteria isolated from cancer patients. International Journal of Infectious Diseases, 10(3), 223-30.

Ruiz-Giardin, J. M., Jimenez, B. C., Martin, R. M., Ortiz, J., Condori Arenas, M. H., Sanmartin, J. V., Cabello, N., Barrios, A. M., Rejas, D., Fuentes Salazar, M., \& Jaquetti, J. (2013). Clinical diagnostic accuracy of suspected sources of bacteremia and its effect on mortality. European journal of internal medicine, 24(6), 541-545.

Shrestha, S., Amatya, R., Shrestha, R. K., \& Shrestha, R. (2014). Frequency of Blood Culture Isolates and their Antibiogram in a Teaching Hospital. Journal of Nepal Medical Association, 52(193), 692-696.

Sweta, O. S., Sanjay, M. J., Kikani, K. M., \& Sunil, O. G. (2016). Bacteriological profile and antibiogram of blood culture isolates from patients of rural tertiary care hospital. International Journal of Microbiology and Mycology, 4(3), 1-7.

Viscoli, C. (2016). Bloodstream Infections: The peak of the iceberg. Virulence, 7(3), 248-51. Wayne, P. A. (2016). Clinical and Laboratory Standards Institute. Performance Standards for Antimicrobial Susceptibility Testing. Twenty-Sixth Informational Supplement. CLSI Document M100-S26. Clinical and Laboratory Standards Institute, p. 50-6.

Weiss, E. S., Makary, M. A., Wang, T., Syin, D., Pronovost, P. J., Chang, D., \& Cornwell, E. E., 3rd (2005). Prevalence of blood-borne pathogens in an urban, university-based general surgical practice. Annals of surgery, 241(5), 803-809. 